\title{
Regional Geochemical Characteristics and Influence Factors of Soil Elements in the Pearl River Delta Economic Zone, China
}

\author{
Lei Dou, Tingting Li \\ Geological Survey of Guangdong Province, Guangzhou, China \\ Email: ggsdl@163.com
}

Received 21 April 2015; accepted 15 June 2015; published 18 June 2015

Copyright (C) 2015 by authors and Scientific Research Publishing Inc.

This work is licensed under the Creative Commons Attribution International License (CC BY). http://creativecommons.org/licenses/by/4.0/

(c) (i) Open Access

\section{Abstract}

Soil heavy metal pollution is one of the main environmental problems in Pearl River Delta Economic Zone of China. Based on multi-purpose regional geochemical survey, regional eco-geochemical assessment, local eco-geochemical assessment and comprehensive appraisal, the eco-geochemical survey and assessment in Pearl River Delta Economic Zone of $41,698 \mathrm{~km}^{2}$ were completed. Samples from soils were collected in accordance with the two-layer grid method. Totally 54 elements and indicators for soils were determined. Compared to deep soils, the sampled surface soils are

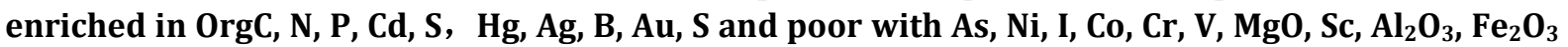
etc. The characteristics of geochemical reference value of element in soil that inherited soil parent material and regional elements combined features reflected that the elements enriched in the soil was interrelated with acid rock, sandstone and shale. The spatial distribution characteristics of element regional geochemistry were conditional by regional environmental geological conditions, and effected by human activities. The Pearl River Delta plain is a typical geochemical landscape area with regional anomaly of multiple-elements. The north, western and eastern parts of the Pearl River Delta Economic Zone are quite different in geochemical features due to regional geological background, soil parent materials, geomorphic characteristics and human activities. Environment quality evaluation results show that the grade I and grade II soil accounted for $19.9 \%$ and $57.3 \%$ of the total area. Many samples that widely distributed in the economic developed of Pearl River Delta Plain area reached the third-grade of national soil environment standard. The soil enriched in $\mathrm{Cd}, \mathrm{Hg}$, As, and the area ratio accounting for $\mathbf{2 2 . 8 \%}$ of the total area. It is mainly controlled by the geochemical background, the Pearl River Delta formation evolution process, especially the marine transgression process lead to $\mathrm{Cd}, \mathrm{Cu}, \mathrm{Zn}$ and $\mathrm{Pb}$ enrichment in Pearl River Delta plain. At the same time, under the influence of higher pressure of human activities, all kinds of exogenous input material carrying heavy metal pollutants on soil environmental quality also could not to ignore. 
Keywords

\section{Regional Geochemical Characteristic, Soil Elements, Source of Anomalous Elements, Influence Factors, Pearl River Delta Economic Zone, China}

\section{Introduction}

In the last three decades, the sustained and rapid socio-economic development of the Pearl River Delta region of China gained a great success, but also paid a heavy price in resources and environment, such as decline in the quantity and quality of natural resources, urban and rural environment pollution, shortage of resources, which seriously restricted the economic development [1]-[7]. In order to provide a scientific basis for socio-economic development and planning to improve the ecological environment of this region, Guangdong Provincial People's Government and China Geological Survey of the Ministry of Land and Resources signed an cooperation agreement of "Eco-geochemical Survey and Assessment in Pearl River Delta Economic Zone of Guangdong Province" in January 2006. This project is part of the multi-purpose geochemical survey program of China.

Ecological geochemistry, as part of application geochemistry, is an edge discipline on the basis of exploration geochemistry. Based on geochemical cycle theory, it deals with the relationship between element geochemical distribution and allocation of state ecological environment through multi-purpose geochemical survey methods [6]. This project includes the multi-purpose regional geochemical survey and ecological geochemical assessment [7]-[9].

Soil and sediment samples from surface and deep soils were systematically collected by means of two-layer grid sampling in the former; different methods were applied in agricultural land ecosystem, shallow water ecosystem and city ecosystem in the latter. Combined with the characteristics of the studied area, we firstly carried out the study of geochemical character of delta formation evolution, the regional radiation environment quality evaluation, the simulation of the effects of acid rain on soil quality and formulation of the local standards for soils environmental quality, and experiment of heavy metal contaminated soil remediation etc.

\section{Description of the Studied Area}

\subsection{Location of the Studied Area}

Pearl River Delta Economic Zone is located in the middle part of Guangdong Province, facing to the South China Sea in the south and is adjacent to Hong Kong and Macao. Its geographic coordinates are $112^{\circ} 00^{\prime}$ $115^{\circ} 24^{\prime} \mathrm{E}, 21^{\circ} 43^{\prime}-23^{\circ} 56^{\prime} \mathrm{N}$ (Figure 1). The land area is $41,698 \mathrm{~km}^{2}$, accounting for about $23.2 \%$ of land area of the whole province. Pearl River Delta Plain, as the major part of the surveyed area, is surrounded by intermittent mountain land and hills in the west, north and east sides. The Pearl River system consists of Pearl River and its tributaries such as Xijiang River, Beijiang River, Dongjiang River and Tanjiang River are arranged in a crisscross pattern. This area belongs to the subtropical monsoon climate, mild and wet with plentiful rainfall. As the pioneer of reform and opening-up, the Pearl River Delta Economic Zone is the important economic central area of our country. Meanwhile, this area is also the growing area for important crops and commercial crops of Guangdong province and the breeding area of aquatic product. It is also developed in the export-oriented agriculture and aquatic product breeding industry.

\subsection{Geological Overview}

Varied and complete strata are widely distributed in the Pearl River Delta Economic Zone, accounting for about $70 \%$ of the whole zone (Figure 1). The outcrops range from Metamorphite series with stronger deformation and metamorphism of Mesoproterozoic era to loose debris sediment of Quaternary period. Quaternary strata are the primary outcrops, others are Nanhua strata, Sinian strata, Cambrian strata, Devonian strata, Carboniferous strata, Jurassic strata, Cretaceous strata etc. Magmatic rocks are mainly composed of the intrusive rock (including the gneissic complex), while the volcanic rocks are only developed in small areas. The intrusive rocks mainly consist of the granite, and then the medium acid monzonite granite, granodiorite and quartz diorite, and other rare types of rocks. Basites are seldom outcropped. The volcanic rocks can be divided into Variscan-Indosinian, Yanshanian and Himalayan according to their formation ages. 


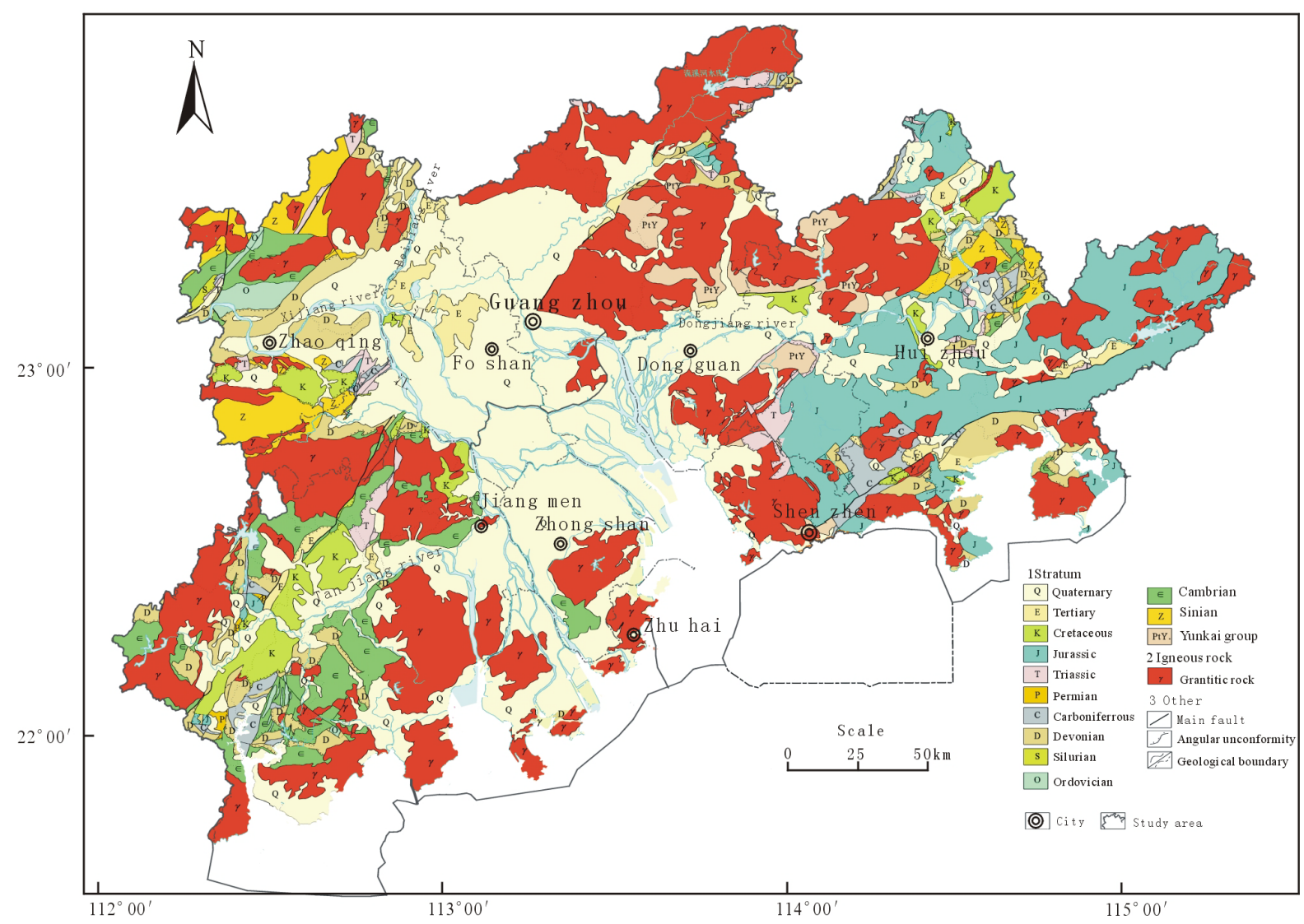

Figure 1. Geological map of the study area.

\section{Materials and Methods}

\subsection{Multi-Purpose Regional Geochemical Survey}

\subsubsection{Sample Collection}

Surface and deep soils were separately collected in terrestrial areas according to two-layer grid sampling. Normally, surface soils were collected at a sampling density of 1 or 2 samples $/ \mathrm{km}^{2}$. Samples from the urban areas of Guangzhou, Foshan, Shenzhen and so on were collected at a sampling density of 2 samples $/ \mathrm{km}^{2}$. All samples were from $0-20 \mathrm{~cm}$ in depth. Four surface soil samples from adjacent grids of land area were combined into one sample for chemical analysis, and single sample of intertidal zone was taken for chemical analysis. Samples from the deep soil of land area at $150-200 \mathrm{~cm}$ depth were collected at a sampling density of 1 sample/4 km². Sixteen deep soil samples from adjacent grids of land area were combined into one sample for chemical analysis, and single sample of intertidal zone was taken for chemical analysis.

Each sample weighed no less than $1000 \mathrm{~g}$. After air-dried, the samples were sieved with 20 mesh screen $(<0.84 \mathrm{~mm})$ and further processed with -200 mesh $(<0.074 \mathrm{~mm})$ for analysis. PH values of soils were measured after sieving with 10 mesh screen $(<2 \mathrm{~mm})$. During the process of sample collecting, transportation, processing and compositing, anti-pollution measures are required.

A total of 43,499 surface soil samples and 10,741 deep soil samples have been collected with 10,908 composite topsoil samples and 2798 composite deep soil samples for analysis.

\subsubsection{Sample Analysis}

Totally 54 elements and indicators, including Ag, As, $\mathrm{Au}, \mathrm{B}, \mathrm{Ba}, \mathrm{Be}, \mathrm{Bi}, \mathrm{Br}, \mathrm{Cd}, \mathrm{Ce}, \mathrm{Cl}, \mathrm{Co}, \mathrm{Cr}, \mathrm{Cu}, \mathrm{F}, \mathrm{Ga}, \mathrm{Ge}$, Hg, I, La, Li, Mn, Mo, N, Nb, Ni, P, Pb, Rb, S, Sb, Sc, Se, Sn, Sr, Th, Ti, Tl, U, V, W, Y, Zn, Zr, $\mathrm{SiO}_{2}, \mathrm{Al}_{2} \mathrm{O}_{3}$, $\mathrm{TFe}_{2} \mathrm{O}_{3}, \mathrm{MgO}, \mathrm{CaO}, \mathrm{Na}_{2} \mathrm{O}, \mathrm{K}_{2} \mathrm{O}$, TC, Corg and $\mathrm{pH}$ for soils (including the intertidal zone) and samples of sediments from offshore marine area were determined. All the samples were analyzed by the Analytical Center of 
the Institute of Geophysical and Geochemical Exploration (IGGE). The analysis method is based on XRF, ICP-MS and ICP-OES test, combined with other advanced sensitive analysis instruments.

External quality control was carried out by analyzing 4 pieces (50 pieces per lot) of blind control samples (BCS), 1327 pieces in total along with the collected samples. Several parameters were then calculated, including qualification rate (\%), correlative coefficients $(\mathrm{r})$ and two-sample variance $(\mathrm{F})$ between the measured value and standard value of BCS 10] (China Geological Survey, 2011). The average qualification rate and detected rate of the BCS analysis quality are $99.81 \%$ and $99.69 \%$ respectively. Internal quality control was performed by analyzing 4 pieces (50 pieces per lot) of BCS. 1723 pieces in total along with the collected samples, re-analyzing 743 blind duplicate samples, accounting for 5.49\% of total samples and checking 36,884 anomalous data. Based on the standard values of certified reference samples, qualification rate (\%) of accuracy and precision $(\lambda)$ were calculated to monitor the accuracy and precision of the analytical methods. According to the results of repeatability checking and anomalous data random-inspection, the qualification rates of relative deviation were calculated to control the analytical accuracy. The average qualification rate of internal inspection is above 99.8\% (Table 1).

Table 1. Analysis method and detection limits for samples.

\begin{tabular}{|c|c|c|c|c|c|}
\hline Elements & Analysis Method & $\begin{array}{c}\text { Method } \\
\text { Detection Limit }^{\mathrm{a}}\end{array}$ & Elements & Analysis Method & $\begin{array}{c}\text { Method } \\
\text { Detection Limit }^{\mathrm{a}}\end{array}$ \\
\hline $\mathrm{Ag}$ & ES & 0.02 & $\mathrm{~Pb}$ & XRF & 2 \\
\hline As & HG-AFS & 1 & $\mathrm{Rb}$ & $\mathrm{XRF}$ & 5 \\
\hline $\mathrm{Au}$ & GF-AAS & 0.0003 & S & XRF & 50 \\
\hline B & ES & 1 & $\mathrm{Sb}$ & HG-AFS & 0.05 \\
\hline $\mathrm{Ba}$ & XRF & 5 & Sc & ICP-MS & 1 \\
\hline Be & ICP-OES & 0.5 & Se & HG-AFS & 0.01 \\
\hline $\mathrm{Bi}$ & ICP-MS & 0.05 & Sn & ES & 1 \\
\hline $\mathrm{Br}$ & XRF & 1.5 & $\mathrm{Sr}$ & $\mathrm{XRF}$ & 5 \\
\hline Cd & ICP-MS & 0.02 & Th & ICP-MS & 1 \\
\hline $\mathrm{Ce}$ & ICP-MS & 1 & $\mathrm{Ti}$ & $\mathrm{XRF}$ & 10 \\
\hline $\mathrm{Cl}$ & $\mathrm{XRF}$ & 20 & $\mathrm{Tl}$ & ICP-MS & 0.1 \\
\hline Co & ICP-MS & 1 & $\mathrm{U}$ & ICP-MS & 0.1 \\
\hline $\mathrm{Cr}$ & $\mathrm{XRF}$ & 5 & $\mathrm{~V}$ & $\mathrm{XRF}$ & 5 \\
\hline $\mathrm{Cu}$ & XRF & 1 & W & ICP-MS & 0.3 \\
\hline $\mathrm{F}$ & ISE & 100 & $\mathrm{Y}$ & ICP-MS & 1 \\
\hline Ga & XRF & 2 & $\mathrm{Zn}$ & XRF & 2 \\
\hline Ge & HG-AFS & 0.1 & $\mathrm{Zr}$ & XRF & 2 \\
\hline $\mathrm{Hg}$ & CV-AFS & 0.0005 & $\mathrm{SiO}_{2}$ & XRF & 0.1 \\
\hline I & COL & 0.5 & $\mathrm{Al}_{2} \mathrm{O}_{3}$ & $\mathrm{XRF}$ & 0.05 \\
\hline $\mathrm{La}$ & ICP-MS & 1 & $\mathrm{TFe}_{2} \mathrm{O}_{3}$ & XRF & 0.05 \\
\hline $\mathrm{Li}$ & ICP-OES & 1 & $\mathrm{MgO}$ & ICP-OES & 0.05 \\
\hline Mn & $\mathrm{XRF}$ & 10 & $\mathrm{CaO}$ & $\mathrm{XRF}$ & 0.05 \\
\hline Mo & ICP-MS & 0.3 & $\mathrm{Na}_{2} \mathrm{O}$ & ICP-OES & 0.02 \\
\hline $\mathrm{N}$ & Combustion-Gas Chromatography & 20 & $\mathrm{~K}_{2} \mathrm{O}$ & $\mathrm{XRF}$ & 0.05 \\
\hline $\mathrm{Nb}$ & $\mathrm{XRF}$ & 2 & $\mathrm{TC}$ & Combustion-Gas Chromatography & 0.1 \\
\hline $\mathrm{Ni}$ & XRF & 2 & Corg & Oxidative Pyrolysis-Potentiometry & 0.1 \\
\hline $\mathrm{P}$ & $\mathrm{XRF}$ & 10 & $\mathrm{pH}$ & Potentiometry & 0.1 \\
\hline
\end{tabular}

${ }^{\mathrm{a}}$ Unit for the content of $\mathrm{SiO}_{2}, \mathrm{Al}_{2} \mathrm{O}_{3}, \mathrm{MgO}, \mathrm{CaO}, \mathrm{Na}_{2} \mathrm{O}, \mathrm{K} 2 \mathrm{O}, \mathrm{C}$ and $\mathrm{Corg}$ is \%; $\mathrm{pH}$ is dimensionless; other measurement unit is $\mu \mathrm{g} \cdot \mathrm{g}^{-1}$. 


\subsection{Eco-Geochemical Assessment}

Ecological geochemical assessment mainly study on the distribution characteristics, origin of sources, migration and transformation and impact mechanism of toxic elements and beneficial elements in the important regional distribution region or local geochemical anomaly area. Rural and urban ecological environment, safety evaluation of agricultural geological suitability and agricultural cultivation had also been studied. A total of 16,514 rock, soil, sediment column, water, suspended solids, chemical fertilizers and pesticides, biological, human hair, wet and dry sedimentation and dust from all types of samples were collected and full-effective volume, shape, composition, physical and chemical indicators were tested, finally 532,100 data were obtained.

\section{Results and Discussion}

\subsection{Regional Geochemical Characteristics}

\subsubsection{Elements Content Characteristics in Soil}

Geochemical parameters of the surface and deep soil samples are shown in Table 2. Content of elements in deep soil and crustal abundance comparative results showed that the soil was enriched in $\mathrm{Bi}, \mathrm{N}, \mathrm{I}$, Cs, Se, B, Hf, As, Sn, Th, W, Pb, U, Tl, Zr, Ce, Tm, Be, Rb, Li, Pr, C, Ta, $\mathrm{Al}_{2} \mathrm{O}_{3}$, Ga, Nd, Dy and Ge, poor with $\mathrm{CaO}, \mathrm{Na}_{2} \mathrm{O}, \mathrm{Sr}, \mathrm{Te}$, MgO, Ni, Mn, Co, Cl, P, Cu, Cd, Au, S, Cr, Lu, $\mathrm{Fe}_{2} \mathrm{O}_{3}, \mathrm{~V}, \mathrm{Sc}, \mathrm{Ti}, \mathrm{Br}, \mathrm{Ho}, \mathrm{Ag}, \mathrm{Gd}, \mathrm{Eu}, \mathrm{Tb}, \mathrm{Hg}, \mathrm{Ba}$, In, Zn, etc.

Table 2. Geochemical background and reference value of elements in soil ${ }^{\mathrm{b}}$.

\begin{tabular}{|c|c|c|c|c|c|c|c|c|c|}
\hline \multirow{2}{*}{ Element } & \multicolumn{2}{|c|}{ Surface } & \multicolumn{2}{|c|}{ Deep } & \multirow{2}{*}{ Element } & \multicolumn{2}{|c|}{ Surface } & \multicolumn{2}{|c|}{ Deep } \\
\hline & $\mathrm{n}^{\mathrm{c}}$ & Background & $\mathrm{n}^{\mathrm{c}}$ & $n^{c}$ & & $\mathrm{n}^{\mathrm{c}}$ & Background & $\mathrm{n}^{\mathrm{c}}$ & Reference \\
\hline $\mathrm{Ag}$ & 9941 & 77 & 2567 & 57 & $\mathrm{~N}$ & 10,266 & 995 & 2602 & 441 \\
\hline As & 9775 & 9 & 2431 & 10.4 & $\mathrm{Nb}$ & 9787 & 18.4 & 2476 & 19 \\
\hline $\mathrm{Au}$ & 9528 & 1.67 & 2614 & 1.34 & $\mathrm{Ni}$ & 9515 & 9.5 & 2529 & 12.9 \\
\hline B & 10,067 & 46.9 & 2541 & 47.4 & $\mathrm{P}$ & 10,098 & 413 & 2585 & 260 \\
\hline $\mathrm{Ba}$ & 10,356 & 293 & 2614 & 304 & $\mathrm{~Pb}$ & 10,062 & 37 & 2526 & 38 \\
\hline $\mathrm{Be}$ & 10,120 & 2.12 & 2562 & 2.34 & $\mathrm{Rb}$ & 10,011 & 117 & 2543 & 124 \\
\hline $\mathrm{Bi}$ & 9530 & 0.77 & 2405 & 0.83 & S & 9911 & 233 & 2387 & 162 \\
\hline $\mathrm{Br}$ & 9985 & 3.8 & 2508 & 2.9 & $\mathrm{Sb}$ & 9827 & 0.68 & 2516 & 0.68 \\
\hline $\mathrm{Cd}$ & 8442 & 69 & 1992 & 45 & Sc & 10,415 & 8.7 & 2625 & 10.6 \\
\hline Ce & 10,150 & 85 & 2530 & 89 & Se & 10,256 & 0.51 & 2600 & 0.52 \\
\hline $\mathrm{Cl}$ & 9376 & 62 & 2294 & 57 & Sn & 9731 & 7.9 & 2556 & 7.8 \\
\hline Co & 9235 & 3.8 & 2413 & 5 & $\mathrm{Sr}$ & 10,365 & 35 & 2611 & 34 \\
\hline $\mathrm{Cr}$ & 10,425 & 40 & 2634 & 47 & Th & 9783 & 19.6 & 2501 & 23.1 \\
\hline Cs & 10,246 & 8.3 & 2567 & 9.8 & $\mathrm{Ti}$ & 10,366 & 3848 & 2610 & 4149 \\
\hline $\mathrm{Cu}$ & 9435 & 12.9 & 2482 & 13.7 & V & 10,433 & 66 & 2634 & 80 \\
\hline $\mathrm{F}$ & 10,275 & 413 & 2580 & 443 & $\mathrm{~W}$ & 9720 & 3.34 & 2541 & 3.78 \\
\hline $\mathrm{Ga}$ & 10,393 & 18.4 & 2619 & 21.6 & $\mathrm{Y}$ & 10,117 & 26.3 & 2523 & 26.7 \\
\hline $\mathrm{Ge}$ & 10,203 & 1.51 & 2599 & 1.62 & $\mathrm{Zn}$ & 10,206 & 50 & 2617 & 51 \\
\hline $\mathrm{Hg}$ & 9420 & 84 & 2511 & 62 & $\mathrm{Zr}$ & 10,210 & 305 & 2588 & 272 \\
\hline I & 10,062 & 3.48 & 2583 & 4.72 & $\mathrm{SiO}_{2}$ & 10,467 & 71.07 & 2642 & 65.36 \\
\hline $\mathrm{La}$ & 10,148 & 38.2 & 2551 & 40.4 & $\mathrm{Al}_{2} \mathrm{O}_{3}$ & 10,414 & 15.1 & 2642 & 18.71 \\
\hline $\mathrm{Li}$ & 10,266 & 28 & 2596 & 32 & $\mathrm{TFe}_{2} \mathrm{O}_{3}$ & 10,436 & 3.73 & 2627 & 4.69 \\
\hline $\mathrm{Mn}$ & 9163 & 213 & 2421 & 221 & OrgC & 10,318 & 1.65 & 2492 & 0.69 \\
\hline Mo & 9600 & 1.11 & 2380 & 1.26 & $\mathrm{pH}$ & 10,404 & 5.28 & 2299 & 5.26 \\
\hline $\mathrm{N}$ & 10,266 & 995 & 2602 & 441 & & & & & \\
\hline
\end{tabular}

${ }^{\mathrm{b}} \mathrm{Unit}$ for $\mathrm{Ag}, \mathrm{Au}, \mathrm{Cd}$ and $\mathrm{Hg}$ is ng. $\mathrm{g}^{-1}$; the unit for $\mathrm{SiO}_{2}, \mathrm{Al}_{2} \mathrm{O}_{3}, \mathrm{TFe}_{2} \mathrm{O}_{3}$ and $\mathrm{OrgC}$ is \%; for the other elements is $\mu \mathrm{g} \cdot \mathrm{g}^{-1}$; $\mathrm{pH}$ is dimensionless. ${ }^{\mathrm{n}} \mathrm{n}$ is the statistical data that eliminated abnormities. 
The results also indicated that the geochemical reference value of soil element was originated from the soil parents' and regional elements combined features reflected that the elements enriched in the soil was interrelated with acid rock, sandstone and shale.

The results indicated that geochemical reference values and background values of the element were inherited from source rocks. Compared with the soil background value, the surface soil of Quaternary sediments relatively enriched in $\mathrm{Au}, \mathrm{Ag}, \mathrm{Cu}, \mathrm{Zn}, \mathrm{Cr}, \mathrm{Ni}$, Cd, Hg, F, As, Sb, Co, P, Mn, B, Ba, V, Ti, Li, Be, Sr, Te, $\mathrm{CaO}, \mathrm{Na}_{2} \mathrm{O}, \mathrm{MgO}$, $\mathrm{Fe}_{2} \mathrm{O}_{3}$, Pr, Nd, Sm, Eu, Gd, Dy, Er, Y, etc.; nearly half of the element background value of the sedimentary source material reached the lowest, including $\mathrm{W}$, Sn, Mo, Pb, Zn, Hg, Mn, Be, Rb, Ta, U, Th, Ga, In, Tl, TC, $\mathrm{K}_{2} \mathrm{O}, \mathrm{Na}_{2} \mathrm{O}, \mathrm{Al}_{2} \mathrm{O}_{3}$, Ce, Pr, Nd, Sm, etc.; background value of U, Th, Sn, Bi, Ta, I, Tl and Tb were significantly higher, while the background of $\mathrm{Au}, \mathrm{Ag}, \mathrm{Cu}, \mathrm{Cr}, \mathrm{Ni}, \mathrm{As}, \mathrm{Sb}, \mathrm{Co}, \mathrm{V}, \mathrm{Ti}, \mathrm{B}, \mathrm{Ba}, \mathrm{MgO}$ were significantly lower; the soil originated from volcanic rocks had a high background value of Mo, Mn, Br, I, Zr, Hf, Nb, Ta, Th and low background value of $\mathrm{Sn}, \mathrm{Bi}, \mathrm{Au}, \mathrm{Cu}, \mathrm{Cr}, \mathrm{Ni}, \mathrm{Cd}, \mathrm{As}, \mathrm{Co}, \mathrm{V}, \mathrm{B}, \mathrm{P}, \mathrm{Ba}, \mathrm{CaO}, \mathrm{Na}_{2} \mathrm{O}$.

\subsubsection{Distribution Characteristics of Elements in Soil}

The Pearl River Delta Plain is a typical geochemical landscape area with spatial distribution of elements. The middle, western and eastern parts of the Pearl River Delta Economic Zone are quite different in geochemical features due to regional geological settings, soil parent materials, geomorphic characteristics and human activities (Figure 2).

Multi-cycle marine deposition and alluviation with a variety of material sources resulted in high content of $\mathrm{N}$, P, $\mathrm{K}_{2} \mathrm{O}, \mathrm{MgO}, \mathrm{CaO}, \mathrm{Na}_{2} \mathrm{O}, \mathrm{Ba}, \mathrm{Mo}, \mathrm{B}, \mathrm{TFe}_{2} \mathrm{O}_{3}$, Mn, Co, Ni, Ti, V, Cr, Sc, Y, REE, Hg, Cd, Pb, As, Cu and Zn in the middle part of the surveyed area [10].

Originating from weathered granite and sandshale ourcropped in the west, there occour many anomalous belts with complex elements combinations, such as the low content area of P, F, Mn, Fe, W, Sn, Zn, $\mathrm{K}_{2} \mathrm{O}, \mathrm{Na}_{2} \mathrm{O}$, Co

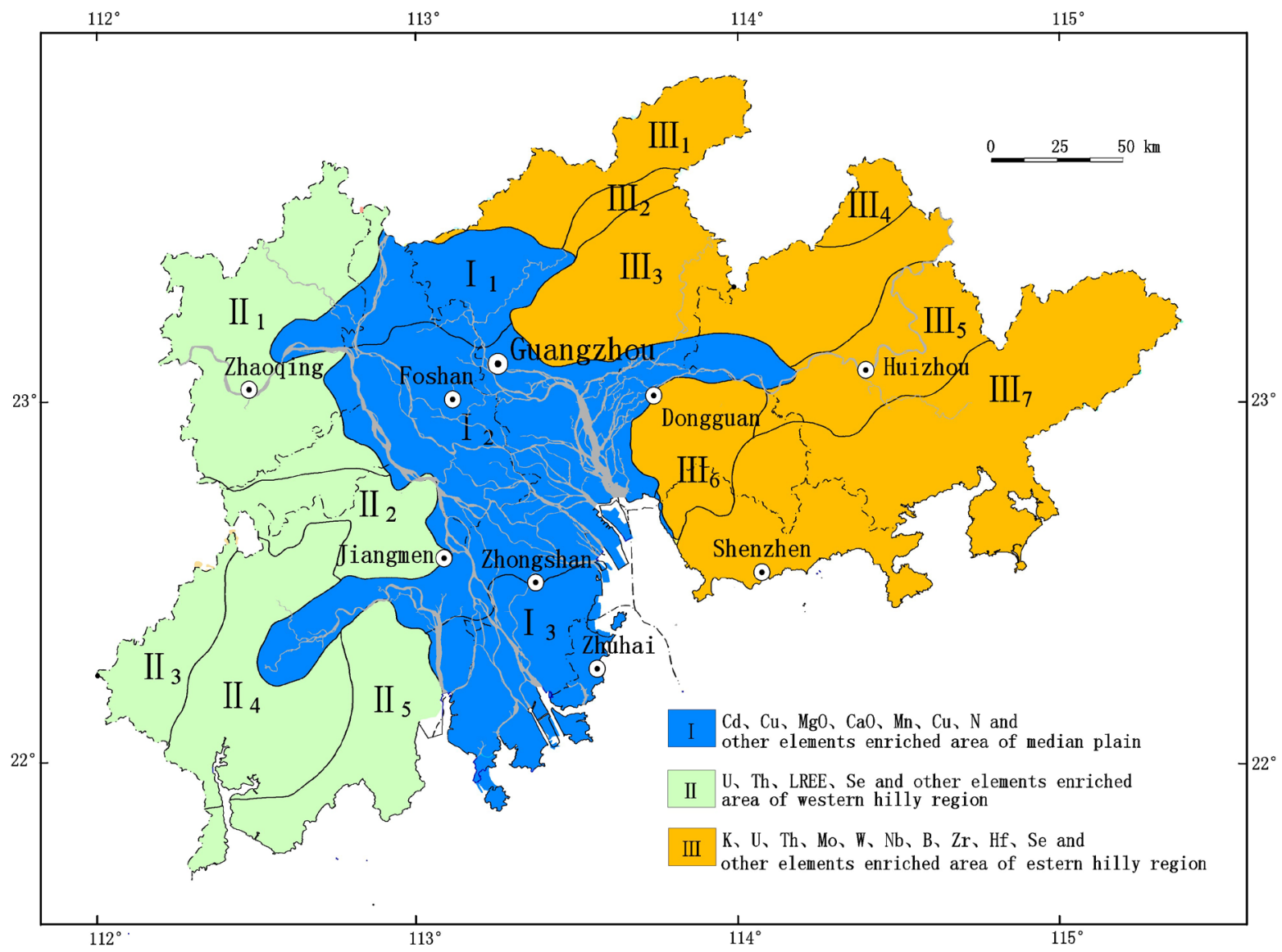

Figure 2. Geochemical zoning map of soil. 
and Mo etc. Along Taishan-Enping, the enriched areas of U, Th and REE in Tianlu Mountains and Gudou Mountains. And selenium-rich soils are widely distributed here, for instance the selenium-rich belts along Taishan-Kaiping-Enping and Zhaoqing-Sihui [10].

The east area features lack of microelements and low background resulted from well-developed old strata such as gneiss and migmatite and volcanic rocks in the south to Dongjiang River [10]. A few high anomalies occur due to mineralization of acid intrusive and extrusive rocks.

\subsection{Geochemical Characteristics of Different Evolution Stage of Pearl River Delta}

Because of the sedimentary dynamic complexity, lateral facies variation and sea level drops erosion during the formation of the Pearl River Delta, many basic problems are still in debate [11]-[14], for example, how many sedimentary cycles took place since the Late Pleistocene. Were there one or two ocean transgressions since Holocene. Were there the last glacial deposits in the studied area. On the basis of the multipurpose regional geochemical analysis, we studied the distribution characteristics of elements in main tectonic framework and sedimentary cycles, through the borehole profiles of Pearl River Delta.

Four sedimentary cycles could be recognizes in the Pearl River Delta of Late Quaternary, on the basis of sedimentology analysis, combined with heavy minerals, grain size, and B, Ba, Sr and other trace element characteristics. Geochemical evolution characteristics of the elements showed that there were three marine transgression events in the Pearl River Delta since Late Quaternary (Table 3, Figure 3), which provided important information for quaternary Environmental Evolution. This study firstly revealed three-dimensional evolution characteristic and the concentration of the elements in sediments of different areas, so as to fill in the gaps of geochemical characteristics texts study in the region, and enhanced the Quaternary research in Pearl River Delta.

\subsection{Ecological Geochemical Assessment}

\subsubsection{Soil Environmental Quality Assessment}

The variation range of $\mathrm{pH}$ was 3.28 - 9.42 and the vast majority of soils are with low $\mathrm{pH}$ values. According to the classification standard of soil acidity and alkaline from the Second Soil Survey (Table 4), the specific land occupation lays on $24544 \mathrm{~km}^{2}$ of strong acidic and acidic soil $(\mathrm{pH} \leq 5.5)$, accounting for $60.1 \%$ of the total area; the specific land occupation lays on $11814 \mathrm{~km}^{2}$ of weak acidic soil (pH 5.5 - 6.5), accounting for $28.9 \%$ of the total area; the specific land occupation lays on $3937 \mathrm{~km}^{2}$ of neutral soil (pH range of 6.5 to 7.5 ) accounting for $9.7 \%$ of the total area and the specific land occupation lays on $514 \mathrm{~km}^{2}$ of alkaline soil ( $\mathrm{pH}>7.5$ ), accounting for $1.3 \%$ of the total area. Statistics found that the acidic soil was mainly composed of the parent materials of diluvial, volcaniclastic rocks, volcanic rocks, granitoids and metamorphic rocks. Parent materials of most neutral soil are marine sediments and paralic sediments. The weak alkaline soils are distributed near the river estuary, which soil parent materials are almost marine sediments. According to geomorphological types, strong acidic and acidic soils are almost distributed in the hill area, while weak acidic soils and neutral soils are distributed in the delta plain. Because of the sub-tropical climate and environment weathering, soils with low $\mathrm{pH}$ values were distributed widely.

According to the soil environmental quality standards [15], the green food production and environmental

Table 3. Characteristics of element content in Vertical deposition system of the Pearl River Delta.

\begin{tabular}{|c|c|c|c|c|c|}
\hline \multirow{2}{*}{ Sedimentary system } & \multicolumn{2}{|c|}{ Depositional sequence } & \multirow{2}{*}{ Element content } & \multirow{2}{*}{ Transgression/Regression } & \multirow{2}{*}{ Sedimentary subfacies } \\
\hline & First cycle & Secondary cycle & & & \\
\hline \multirow{4}{*}{ Holocene } & \multirow{4}{*}{ II } & \multirow{2}{*}{2} & High & Transgression & Delta plain facies/Delta-front facies \\
\hline & & & Low & Local regression & Delta plain facies \\
\hline & & \multirow{2}{*}{1} & High & Transgression & Prodelta/Delta-front facies \\
\hline & & & Low & Regression & Fluvial facies/Weathering period \\
\hline \multirow{2}{*}{ Late Pleistocene } & \multirow{2}{*}{$\mathrm{I}$} & 2 & High & Transgression & Delta plain facies \\
\hline & & 1 & Low & Regression & Fluvial facies \\
\hline
\end{tabular}



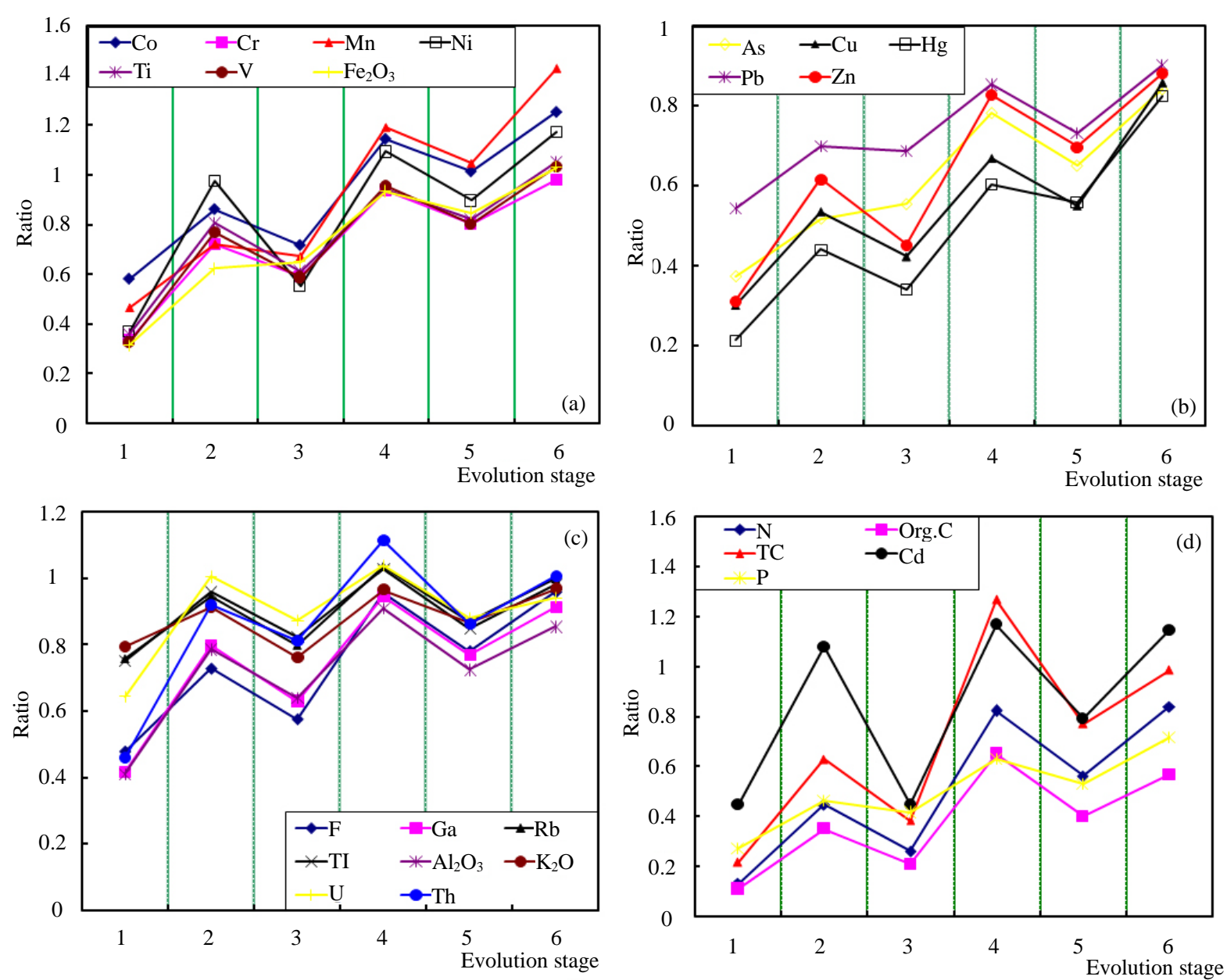

note: Ration is the element content of each evolution stage to surface soil;

The number of 1, 3 and 5 denotes transgression, 2, 4 and 6 denotes regression.

Figure 3. Changes of the typical element contents in transgressive and regressive process of the Pearl River Delta.

Table 4. Soil pH classing standards and classification results.

\begin{tabular}{cccccc}
\hline Class & Alkaline & Neutral & Weak acid & Acid & Strong acid \\
\hline $\mathrm{pH}$ & $>7.5$ & $6.5-7.5$ & $5.5-6.5$ & $4.5-5.5$ & $\leq 4.5$ \\
Proportion (\%) & 1.26 & 9.73 & 28.92 & 60.06 & 0.04 \\
Area $\left(\mathrm{km}^{2}\right)$ & 514 & 3973 & 11814 & 24529 & 15 \\
\hline
\end{tabular}

quality standards and other relevant standards [16], the results of soil environmental quality evaluation showed that the soil environmental problem of the region was serious (Figure 4). Many samples that widely distributed in the economic developed Pearl River Delta Plain area reached the third-class national soil Environment standard. The soil enriched in Cd, Hg, As, and the area ratio accounting for $22.8 \%$ of the total area. First-class soil and second-class soil that suitable for agricultural cultivation land account for $19.9 \%$ and $57.3 \%$ of the total area of $41,698 \mathrm{~km}^{2}$. Environmental quality green agricultural area is $21,847 \mathrm{~km}^{2}$, accounting for $52.4 \%$ of the total area.

\subsubsection{Ecological Effect}

Element test on As, Cd, Hg, Pb, Cr, F, Cu, Zn, Ni and Se have been carried out, based on 805 samples, including vegetables, rice and fruit from agriculture growing area. Statistic result revealed that the association and compo- 
sition of these elements from different kinds of crops were quite different (Figure 5). Rice was the most prominent, which had an average content of $\mathrm{Cr}, \mathrm{As}, \mathrm{Cd}, \mathrm{Pb}, \mathrm{Cu}, \mathrm{Zn}$ of $0.67 \mathrm{mg} \cdot \mathrm{kg}^{-1}, 0.15 \mathrm{mg} \cdot \mathrm{kg}^{-1}, 0.13 \mathrm{mg} \cdot \mathrm{kg}^{-1}, 0.23$ $\mathrm{mg} \cdot \mathrm{kg}^{-1}, 4.25 \mathrm{mg} \cdot \mathrm{kg}^{-1}$ and $9.75 \mathrm{mg} \cdot \mathrm{kg}^{-1}$.

Based on "Maximum levels of contaminants in foods" [17], "Tolerance limit of copper in foods" [18], "Tolerance limit of zinc in foods" [19] and "Tolerance limit of arsenic in foods" [20], various types of crops edible part of safety had been studied in this survey. The results showed that 87 samples were over standard with a total rate of $10.42 \%$. The over standard rate of $\mathrm{Cd}$ and $\mathrm{Pb}$ were $5.75 \%$ and $5.39 \%$, which are the mainly polluted elements. The over standard rate of $\mathrm{Cr}, \mathrm{Zn}, \mathrm{Cu}, \mathrm{Hg}$ were $1.80 \%, 1.80 \%, 0.72 \%$ and $0.36 \%$ in small amount of samples. As didn't exceed the standard. From the results of the classification and evaluation of different types of crops, the exceeding standard rate of heavy metals such as $\mathrm{Cd}$ and $\mathrm{Pb}$ were high in rice and vegetables. The over standard of $\mathrm{Cd}, \mathrm{Pb}$ and $\mathrm{Zn}$ were lower in beans and cucurbits.

\subsection{Source of Typical Anomalous Elements in Soil}

Heavy metal elements anomalies along the Yangtze River is an major ecological environmental issue discovered by the multi-purpose geochemical survey that is being carried out in China [21] made systematical studies on methodology of the source tracking and quantitative estimation of the elements anomalies along Yangtze River. Heavy metal elements anomalies along the Pearl River is similar to Yangtze River [22]. The result shows, high content elements such as $\mathrm{Cd}, \mathrm{Cu}, \mathrm{Pb}, \mathrm{Zn}, \mathrm{Cr}, \mathrm{F}$ were regional distributed. The distribution range was in accordance with those of Guizhou Formation and Lile Formation, which typically controlled by geologic background. Studies on the typical strata, rock and mine, element distribution characteristics of binding rock and ore mineral assemblages of the middle and upper reaches of the Pearl River Basin, Pb isotopic composition and the evolution geochemical characteristics of delta formation showed that sediments were mainly from the upstream parent rock debris material. Material source, sediment grain size and depositional environment affected the distribution characteristics of the Pearl River Delta Quaternary sediments in $\mathrm{Cd}, \mathrm{Pb}, \mathrm{Zn}$, other heavy metals and high content sources and migration enrichment patterns. Among all the factors, material source played an important role in

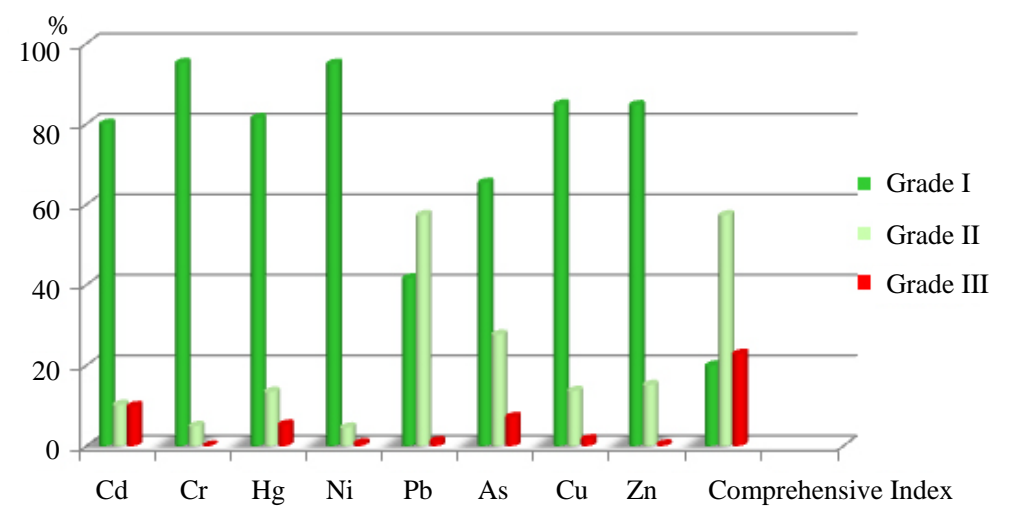

Figure 4. The ratio of each graded soil distribution to the surveyed area.
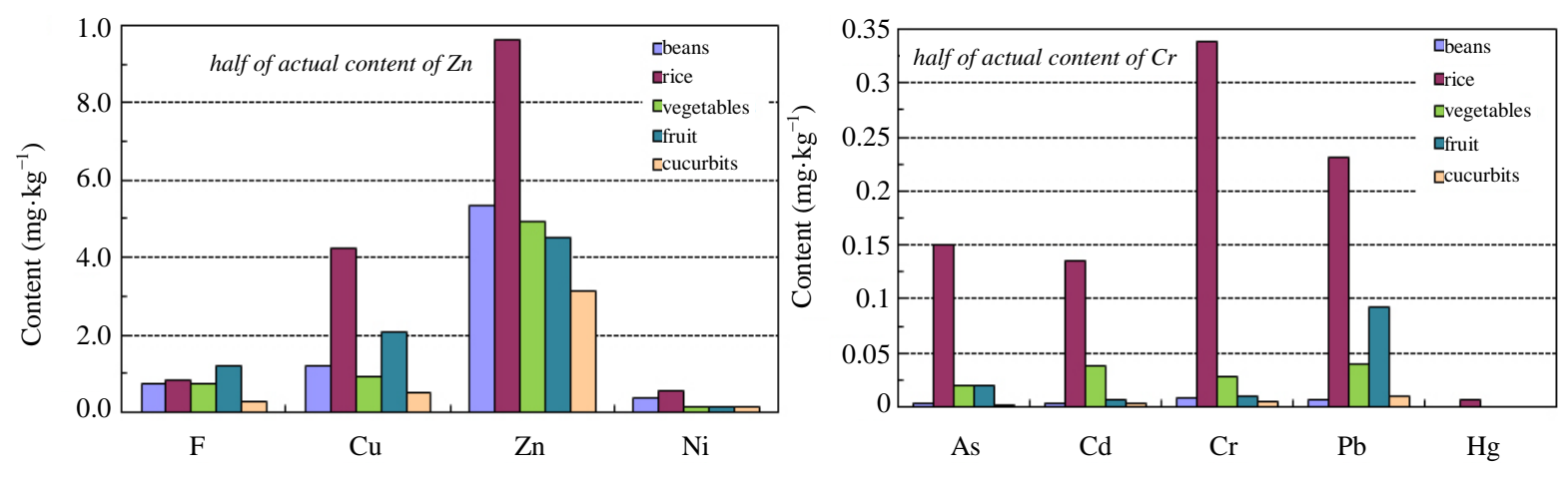

Figure 5. The average content of heavy metals in different varieties of crops. 
the concentration of the elements. Materials from the upstream catchment area of the Pearl River system affected the geochemical characteristics of the delta plain soil elements [22].

Pearl River system not only provided materials for the formation of Pearl River Delta in geological history, but also continued to carry a large number of debris particles and dissolved substances into the delta plain. It became an important source of the water elements in the plain rivers. The element fluxes were calculated according to the survey of suspended solids and filtered water element content of the Pearl River Delta, the Dongjiang River, the Beijiang River, Xijiang River, Tanjiang River, Liuxihe River. The results were showed in Table 5. Seen from Table 5, Ca, Mg, Na were maximally transported to the delta plain by Pearl River system, about million tons every year; $\mathrm{K}, \mathrm{Al}, \mathrm{Sr}, \mathrm{P}, \mathrm{Tl}$, Mn went secondly, more than ten thousand tons every year; $\mathrm{K}, \mathrm{Al}, \mathrm{Sr}, \mathrm{P}$, Tl, Mn went thirdly, thousands of tons every year; Ni, REE, As, Pb were about hundreds of tons every year; Co, $\mathrm{Cd}, \mathrm{Hg}$, In were relatively less, about several to tens of tons every year. Generally, influx of the main heavy metal elements, including As, $\mathrm{Cd}, \mathrm{Cu}, \mathrm{Hg}, \mathrm{Pb}, \mathrm{Zn}$, in different rivers arranged as Xijiang River > Beijiang River > Dongjiang River. Xijiang River was an important source of heavy metals to the Pearl River delta.

But under the influence of the high intensity of human activities, a variety of exogenous input materials carried by heavy metal pollutants on soil environmental quality can not be ignored. The total input flux for external source pollution pathway such as atmospheric deposition, fertilization, irrigation, pesicides was shown in Table 6. Atmospheric deposition and irrigation were the main input pathways for $\mathrm{Cr}, \mathrm{Cd}, \mathrm{Zn}, \mathrm{Ni}, \mathrm{Pb}, \mathrm{Hg}, \mathrm{Cu}$, while fertilization might serve as the important pathway for $\mathrm{F}$ input.

Table 5. Major element flux carried into the pearl river delta plain by the pearl river system ${ }^{\mathrm{d}}$.

\begin{tabular}{|c|c|c|c|c|c|c|}
\hline Element & Dongjiang River & Beijiang River & Xijiang River & Liuxihe River & Tanjiang River & Total \\
\hline As & 80.7 & 136.2 & 454.3 & 10.8 & 7.1 & 689.1 \\
\hline $\mathrm{Ca}$ & 263,284 & $1,250,796$ & $11,433,872$ & 98,364 & 91,018 & $13,137,334$ \\
\hline $\mathrm{Cd}$ & 1343.6 & 5596.6 & 21912.6 & 455.3 & 306.9 & 29,615 \\
\hline Co & 11.9 & 9.2 & 63.7 & 4.0 & 2.1 & 90.9 \\
\hline $\mathrm{Cu}$ & 217.1 & 153.9 & 606.2 & 55.6 & 27.8 & 1060.6 \\
\hline $\mathrm{Hg}$ & 166.0 & 270.5 & 2053 & 62.2 & 39.0 & 2590.7 \\
\hline In & 203.2 & 267.8 & 1124.1 & 70.8 & 35.6 & 1701.4 \\
\hline K & 73309 & 99,459 & 415,838 & 23,716 & 34,726 & 647,048 \\
\hline $\mathrm{Mg}$ & 46774 & 154,052 & $1,502,493$ & 11,351 & 33,301 & $1,747,971$ \\
\hline Mn & 1966.2 & 1673.4 & 8995.7 & 557.1 & 372.2 & 13564.6 \\
\hline $\mathrm{Na}$ & 166,091 & 272,058 & 896,219 & 121,843 & 253,882 & $1,710,093$ \\
\hline $\mathrm{Ni}$ & 192.6 & 140.4 & 557.2 & 68.5 & 29.9 & 988.7 \\
\hline $\mathrm{P}$ & 3718 & 1738 & 20,504 & 1234 & 791 & 27,985 \\
\hline $\mathrm{Pb}$ & 64.6 & 70.2 & 253.2 & 19.6 & 9.2 & 416.9 \\
\hline REE & 228.3 & 122.6 & 456.1 & 39.7 & 31.3 & 878 \\
\hline $\mathrm{Sb}$ & 6.4 & 50.3 & 937.6 & 4.8 & 3.0 & 1002.1 \\
\hline $\mathrm{Sr}$ & 821.3 & 2744.8 & 30,620 & 266.4 & 367.7 & 34820.8 \\
\hline $\mathrm{Tl}$ & 2068 & 9094 & 15,436 & 253 & 633 & 27,483 \\
\hline $\mathrm{Zn}$ & 445.5 & 976.4 & 3706.7 & 125.5 & 102.5 & 5356.6 \\
\hline
\end{tabular}

${ }^{\mathrm{d}} \mathrm{Unit}$ for Be, Bi, Cd, Hg, In, $\mathrm{Tl}$ is $\mathrm{kg} \cdot \mathrm{a}^{-1}$, for the other elements is $\mathrm{t} \cdot \mathrm{a}^{-1}$. 
Table 6. The ratio of elements from different sources to the total exogenous input elements.

\begin{tabular}{ccccccccccc}
\hline Proportion (\%) & $\mathrm{Cr}$ & $\mathrm{Cd}$ & $\mathrm{Zn}$ & $\mathrm{Ni}$ & $\mathrm{Pb}$ & $\mathrm{As}$ & $\mathrm{Hg}$ & $\mathrm{Cu}$ & $\mathrm{F}$ \\
\hline Rainfall and fallen dust & 80.76 & 85.76 & 67.55 & 22.66 & 22.86 & 66.44 & 67.04 & 57.22 & 31.19 \\
Irrigation & 13.17 & 12.28 & 29.97 & 75.39 & 72.30 & 26.02 & 23.09 & 38.87 & 18.80 \\
fertilization & 5.93 & 1.95 & 2.47 & 1.95 & 4.72 & 7.59 & 8.81 & 3.90 & 50.01 \\
Pesticides & 0.15 & 0.003 & 0.001 & 0.006 & 0.003 & 0.015 & 0.010 & 0.011 & 0.02 \\
\hline
\end{tabular}

\section{Conclusions}

This project carried out the most systematic and comprehensive survey in the Pearl River Delta economic zone. Multi medium, multiple indexes of high precision for geochemical data have been obtained and detailed land quality of the Pearl River Delta economic zone also have been systematically investigated, through regional eco-geochemistry assessment, and studying the elementary composition, distribution, origin, transport process and impact mechanism of the regionally distributed toxic and beneficial elements.

Compared to deep soils, the sampled surface soils are enriched in OrgC, N, P, Cd, S, Hg, Ag, B, Au, S and poor with As, Ni, I, Co, Cr, V, MgO, Sc, $\mathrm{Al}_{2} \mathrm{O}_{3}, \mathrm{Fe}_{2} \mathrm{O}_{3}$, etc. The characteristics of geochemical reference value of element in soil that inherited soil parent material and regional elements combined features reflected that the elements enriched in the soil was interrelated with acid rock, sandstone and shale. The spatial distribution characteristics of element regional geochemistry were conditional by regional environmental geological conditions, and effected by human activities. The Pearl River Delta plain is a typical geochemical landscape area with regional anomaly of multiple-element. The north, western and eastern parts of the Pearl River Delta Economic Zone are quite different in geochemical features due to regional geological background, soil parent materials, geomorphic characteristics and human activities.

Environment quality evaluation results show that the first-class and second-class soil in the area accounted for $19.9 \%$ and $57.3 \%$ of the total area. Many samples that widely distributed in the economic developed Pearl River Delta Plain area reached the third-class national soil environment standard. The soil enriched in Cd, Hg, As, and the area ratio accounting for $22.8 \%$ of the total area. It is mainly controlled by the geochemical background, the Pearl River Delta formation evolution process, especially the marine transgression process lead to $\mathrm{Cd}, \mathrm{Cu}, \mathrm{Zn}$ and $\mathrm{Pb}$ enrichment in Pearl River Delta. At the same time, under the influence of higher pressure of human activities, all kinds of exogenous input material carrying heavy metal pollutants on soil environmental quality also cannot to ignore.

\section{Funds}

This work was financially supported by the China Geological Survey Project (1212010511216, GZTR20080329) and Environmental Protection Special Fundation of Guangdong Provincial (Guangdong environment [2014] 126).

\section{References}

[1] Bai, J.H., Xiao, R., Cui, B.S., Zhang, K.J., Wang, Q.G., Liu, X.H., Gao, H.F. and Huang, L.B. (2011) Assessment of Heavy Metal Pollution in Wetland Soils from the Young and Old Reclaimed Regions in the Pearl River Estuary, South China. Environmental Pollution, 159, 817-824. http://dx.doi.org/10.1016/j.envpol.2010.11.004

[2] Wong, S.C., Li, X.D., Zhang, G., Qi, S.H. and Min, Y.S. (2002) Heavy Metals in Agricultural Soils of the Pearl River Delta, South China. Environmental Pollution, 119, 33-44. http://dx.doi.org/10.1016/S0269-7491(01)00325-6

[3] Zhou, G.H., Xie, X.J. and Liu, Z.Y. (2004) Potential Ecological Risk Assessment of Heavy Metal in Soils in the Zhujiang River Delta: Heavy Metal Activation in Soils. Geological Bulletin of China, 23, 1088-1093.

[4] Zhu, Y.G., Chen, B.D., Lin, A.J., Ye, Z.H. and Huang, M.H. (2005) Heavy Metal Contamination in Pearl River DeltaStatus and Research Priorities. Acta Scicetiae Circumstantiae, 25, 1575-1579.

[5] Zhou, Y.Z., Shen, W.J., Li, Y. and Dou, L. (2012) A Study of Prediction and Early-Warning Forecast on Geochemical Accumulation of Soil Heavy Metals Based on Flux Model in Pearl River Delta Economic Zone (China). Advances in Earth Science, 27, 1115-1125. 
[6] Xi, X.H. (2004) Eco-Geochemical Research and Eco-Geochemical Evaluation. Geophysical \& Geochemical Exploration, 28, 10-15.

[7] Xi, X.H. (2005) Multi-Purpose Regional Geochemical Survey and Ecogeochemistry: New Direction of Quaternary Research and Application. Quaternary Sciences, 25, 269-274.

[8] Yang, Z.F., Cheng, H.X., Chen, Y.L., Feng, H.Y., Chen, D.Y., Chen, G.G. and Zhao, G.X. (2004) Exploration Geochemistry in 21st Century: Prospects for Ecological Geochemistry. Earth Science Frontiers, 11, 600-605.

[9] Yang, Z.F., Xi, X.H., Cheng, H.X., Zhou, G.H., Chen, D.Y., Zhang, J.X., Yuan, X.J., Feng, H.Y., Chen, J.W., Liu, A.H., Tang, Q.F. and Yu, T. (2005) The Core and Countermeasures of Regional Ecological Geochemical Assessment. Quaternary Sciences, 25, 275-284.

[10] China Geological Survey (2011) Multi-Purpose Geochemical Altas of Pearl River Delta Economic Zone, Guangdong Province, China. Geological Press of China, Beijing, 6-109.

[11] Fang, G.X., Li, P.R. and Huang, G.Q. (1991) Sea Level Changes in Pearl River Delta during the Past 8000 Years. Geographical Research, 10, 1-11.

[12] Huang, Z.G., Li, P.R. and Zhang, Z.Y. (1982) The Formation and Evolution of Pearl River Delta. Guangzhou Branch of Popular Science Press, Guangzhou, 40-50.

[13] Lan, X.H., Ma, D.X., Xu, M.G., Zhou, Q.W. and Zhang, G.W. (1987) Some Geochemical Indicators of the Pearl River Delta and Their Facies Significance. Marine Geology \& Quaternary Geology, 7, 39-49.

[14] Long, Y.Z. and Huo, C. (1990) The Sedimentation Characteristics of Zhujiang River Delta in Late Quaternary. Marine Science, 4, 7-14.

[15] GB15618 (1995) Soil Environmental Quality Standards in China. Ministry of Environmental Protection of China, Beijing.

[16] NYT391 (2000) Green Food-Technical Conditions for Environmental of Area. Ministry of Agriculture, PRC, Standards Press of China, Beijing.

[17] GB2762 (2005) National Committee of Standardization. Maximum Levels of Contaminants in Foods. Ministry of Health, PRC, Standards Press of China, Beijing.

[18] GB15199 (1994) Tolerance Limit of Copper in Foods. Ministry of Health, PRC, Standards Press of China, Beijing.

[19] GB13106 (1991) Tolerance Limit of Zinc in Foods. Ministry of Health, PRC, Standards Press of China, Beijing.

[20] GB4810 (1994) Tolerance Limit of Arsenic in Foods. Ministry of Health, PRC, Standards Press of China, Beijing.

[21] Cheng, H.X., Yang, Z.F., Xi, X.H. and Zhao C.D. (2005) A Research Framework for Source Tracking and Quantitative Assessment of the Cd Anomalies along the Yangtze River Basin. Earth Science Frontiers, 12, 261-272.

[22] Liu, Z.N., Dou, L. and Zhang, W. (2102) Distribution and Origin of Cadmium in the Quaternary Sediments of the Pearl River Delta Plain, Guangdong Province, Southern China. Geological Bulletin of China, 31, 172-180. 